\title{
Upstream Stimulatory Factor 1
}

National Cancer Institute

\section{Source}

National Cancer Institute. Upstream Stimulatory Factor 1. NCI Thesaurus. Code C38368.

Upstream stimulatory factor 1 (310 aa, $~ 34$ kDa) is encoded by the human USF1 gene.

This protein plays a role in the positive regulation of gene transcription. 